\title{
Dez anos do Curso de Enfermagem da Faculdade de Medicina do ABC: e os desafios continuam
}

\author{
Ten years of Nursing Graduation at Faculdade de Medicina do ABC: \\ the challenges continue
}

Maria Belén Salazar Posso'

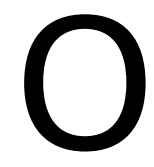

Curso de Enfermagem da Faculdade de Medicina do ABC (CEFMABC) foi autorizado a funcionar pelo Parecer CEE/SP n.419/98 e reconhecido pelo Parecer CEE/SP n. 306/2003. Assim, em 1999 iniciou-se o CEFMABC com 50 vagas e até 2008 formou sete turmas, das quais muitos enfermeiros têm sido absorvidos pela região do ABC e Grande São Paulo.

O CEFMABC entende que a região promove a diversidade do campo de atuação, evidencia a problemática do cotidiano prático, determina a realidade para a assistência, influencia os processos de formação, exige o trabalho em equipe e a interdisciplinaridade para implementar seu currículo pleno. Dessa forma, este curso acompanha o desenvolvimento contextual da sociedade englobando sua filosofia, sua economia, suas leis e sua ideologia, às quais estão intimamente associadas. Sociedade essa, em que as mudanças ocorrem de forma acelerada, complexa, paradoxal, retratadas nas mudanças demográficas, na explosão tecnológica, nos avanços na pesquisa e ciência de enfermagem, na globalização socioeconômica, na saúde como um bem de consumo e no aumento da procura por um cuidado complementar e paliativo. Também acompanha um mercado de trabalho em que se diferencia, aquele que é competente, que exibe uma consciência crítica e compromisso com as dimensões téorico-práticas da profissão em que está inserido.

Então, o CEFMABC tem o aluno como centro de suas atenções, formando-os para serem cidadãos socialmente responsáveis capazes de enfrentar desafios; descobrir e buscar novos conhecimentos e métodos em sua atuação profissional, agregando à ciência, valores humanísticos, éticos e morais e compromissados com a promoção da saúde do ser humano e da coletividade.

Nestes dez anos de existência, o CEFMABC pautou seu processo de ensino e aprendizagem na crença de que o homem é um ser vivo, racional, social, espiritual e membro de uma espécie, portanto, é inerente: o respeito, a inteligência, a conservação, a liberdade e que o cuidar do enfermeiro deve estar voltado para a pessoa e não para pacientes e deve estar fundamentado nos princípios científicos, filosóficos, sociais, psicológicos, socioantropológicos e gerenciais.

Este suplemento, inserido na revista Arquivos Brasileiros de Ciências da Saúde, comemorando os dez anos da implantação do CEFMABC se faz presente com uma coletânea dos resumos de trabalhos de conclusão de curso de seus alunos, hoje enfermeiros. Essa inovação cria uma modalidade de divulgação que incita a investigação científica dos estudantes, estimula sua criatividade e capacidade de problematizar e desenvolver, sistemática e metodologicamente, pesquisas em temas contextualizados a partir de suas vivências teórico-práticas no decurso de suas atividades acadêmicas. Nada mais justo! Assim como o ser humano é o objeto das ações do enfermeiro, o aluno também é para os docentes do CEFMABC.

Finalmente, parabéns a todos que fizeram desses dez anos do CEFMABC um acontecimento ímpar na vida acadêmica da FMABC e da saúde da região do $\mathrm{ABC}$ e continua caminhando no sentido de sempre otimizar os processos do ensino/aprendizagem, da pesquisa e da extensão para colaborar com a sociedade em geral. 